\begin{tabular}{l}
\hline sciendo $\frac{\text { ECONOMIC THEMES (2018) 56(4): 503-517 }}{\text { DOI 10.2478/ethemes-2018-0029 }}$ \\
\hline
\end{tabular}

\title{
DISCRIMINANT ANALYSIS - USEFUL TOOL FOR PREDICTING DEMAND IN SERBIAN MOTELS
}

\author{
Lazar Pavić \\ Economics Institute, Belgrade \\ PhD student, Faculty of Sciences, University of Novi Sad, Serbia \\ $\triangle$ lazar.pavic@dgt.uns.ac.rs \\ Božidar Veljković \\ Alma Mater Europaea - European center, Maribor, Slovenia \\ $\square$ bozidar.veljkovic@siol.net \\ Bojan Sešel \\ Higher professional school,Celje, Slovenia \\ $\square$ bojan.sesel@guest.arnes.si \\ UDC \\ 519.8:339.13 \\ Original \\ scientific \\ paper

\begin{abstract}
In this paper, a discriminant analysis, as useful tool to predict potential demand in Serbian motels, is presented. Through the presented literature review, it was determined that there is not a large number of surveys dealing with the needs and demand of transit tourists. Despite that, transit tourism is one of the priority forms of tourism for the Republic of Serbia in accordance with the established Tourism Development Strategy for the Republic of Serbia for the current period. Questionnaire survey as the main method for data collection is used. According to the results, 14 dimensions of potential guests' expectations are extracted. The results of discriminant function analysis (DFA) present the impact of potential motel guests' expectations on the main reason for travelling, while the results of canonical varieties analysis (CVA) present the impact of potential motel guests' expectations on preferred services in Serbian motels.
\end{abstract}

Received:

07.11.2018

Accepted:

28.12.2018
Keywords: Discriminant Analysis, motel, guests' expectations dimensions, Serbia, hospitality management, transit tourism

JEL classification: Z31

* The paper was presented on the $49^{\text {th }}$ International Scientific Conference "Quantitative and Qualitative Analysis in Economics", held in Niš on 18 October 2018.

* This work was supported by the Project no. III 46001, financed by the Ministry of Education, Science and Technological Development of Republic of Serbia. 


\section{Introduction}

Discriminant Analysis presents one of the statistical methods from the group of methods for studying dependency. The main objective of discriminant analysis is to assess the adequacy of classification, given the group membership or to assign objects to one group among a number of groups. When a discriminant analysis is used to separate two groups, we refer to Discriminant Function Analysis (DFA) or simple discriminant analysis, while when there are more than two groups - the Canonical Varieties Analysis (CVA) or multiple discriminant analysis is used (Bastič, 2006).

Discriminant Analysis has a few benefits as a statistical tool. It is quite similar to a regression analysis. It is useful to determine predictor variables related to the dependent variable. Discriminant Analysis can also predict the value of the dependent variable through giving the certain values of the predictor variables.

The important usage of this method is also its ability to identify those variables, which contributes most to the group separation through the allocation of the observation into predefined groups (Kovačić, 1994).

Using the discriminant analysis is very useful when independent variables are numeric, and dependent variable is categorical (nominal or ordinal). The original variables, which describe entities, are often called predictors, while variables, which determine entities belonging to the particular group, are called criterion or group variables (Tabachnick \& Fidell, 2007).

Motels are an important part of the hospitality industry, defined as hospitality facilities, which provide accommodation and parking. Their rooms should be easily accessible from the outdoor area. Motels usually provide short stay accommodation and they do not offer other additional services as hotels do, such as: fitness centre, wellness centre, conference rooms, different type of restaurants (Clemes et al., 2011).

Motels usually differ in offered services among country of its location. In New Zealand, the most number of motels offer basic services in smaller capacity, usually between fifteen do forty rooms per facility. These motels offer guests different experiences during their visits, comparing with motels with higher number of rooms and other services included. There are over thousands motels in New Zealand, and they had about 33\% in all number of overnight stays in hospitality facilities in 2010 with $52 \%$ of capacity uptake (Mair \& Bergin-Seers, 2010).

In Australia, motels are in the most cases small capacity facilities owned by individuals or families. The first motels were built in Australia in parallel with cars popularization (Bergin-Seers \& Jago, 2007). Motels are in appropriate accommodation facilities for both business travellers and transit tourists. Much of them also offer different restaurants and conference rooms and facilities for business travellers (Mair \& Bergin-Seers, 2010). 
Motels in Taiwan offer different services. Since the most important factor for motel accommodation selection in Taiwan is room atmosphere, motel managers focus on atmosphere, unique style and design, and new equipment to attract guests. These motels are usually located near main roads and in city outskirts and offer parking and accommodation service with contemporary equipment and elegant design. The other competitive advantages of these motels are six stats category and exotic and thematic apartments (Wu \& Chen, 2012).

The nature of motel services near main roads requires different components of guests' demand. Motels near main roads serve also local population and firms from the local environment, but also transit tourists who are resting because of a long travel. They choose their destination to stay among different hospitality facilities on the road and the others are favoured (Mazzeo, 2004).

The sudden development of the road traffic in the second half of the 20th century was the basis for the construction of various contents along the road in Yugoslavia (Serbia). The most important services and material bases present on motorways are related to vehicles (petrol pumps, automobile mechanics and car services). As human is the one who manages a car, a significant segment of services is adjusted to him/her. Thus, various types of catering facilities had been developed for providing food, beverage and beverage services (restaurants, cafes, various seasonal checkpoints), and later motels as hospitality facilities for transit tourists (Garača et al., 2008). After the Second World War, the development of hospitality was promoted as an economic activity, while the intensive construction of motels as hospitality facilities has prompted a sharp increase in the number of passenger vehicles since the 1960s (Knežević \& Grbac Živković, 2013).

Today in Serbia, there are eight categorised catering facilities for accommodation of the motel type. The largest number of motels in Serbia are of the lowest category (four motels) while there are no facilities of the motel type of the highest category (four stars). From the 188 accommodation units in Serbian motels, the apartments are only $5.85 \%$, while the other units are of the room type. The total accommodation capacity is 342 beds, which represents only $1.12 \%$ of the total number of beds in categorised catering facilities for accommodation in July 2018 (MTTT, 2018).

As opposed to the little number of beds in Serbian motels, the potential of transit tourism development in Serbia is big. Transit tourism as a set of relationships and occurrences emerged because of all significant factors related to the movement of tourists through different places, regions or countries, to the destination of their journey. Their retention is limited primarily to the goal of stopping, ranging from several minutes to one or more overnight stays (Štetić, 1984). The destination of transit tourism can therefore be any place that is available through the usual means of transport. Nevertheless, most of the transit movements take place along major communications and in their gravitational areas (Štetić, 
1999). Horak (2004) defines transit tourism as a set of relationships and occurrences that arise because of the needs of tourists who are traveling through areas that do not represent neither the source nor the purpose of travel.

The Tourism Development Strategy of the Republic of Serbia for the period from 2016 to 2025 (MTTT, 2018) emphsises transit tourism as one of the tourism products of particular importance for tourism development. The importance of the geostrategic position of Belgrade and the Republic of Serbia at the intersection of European corridors 7, 10 and 11 and the transit state of the state itself is particularly accentuated. In addition, the strategy highlights the great business potential of these corridors and the lack of quality camps, motels, holiday destinations with a variety of content and attractive programmes, especially through the implementation of good practices from countries that have tradition and success in providing services to transit tourists.

One of the essential elements for every form of tourism, even for transit tourism, certainly represents a material base. It is often a crucial factor in choosing a tourist destination. In their study, Kovačević and Obradović (2006) emphasise that the utilization of capacity in the transit tourism of the municipality of Subotica is small, and that this is the prevailing reason for high prices. It is further emphasised that in the municipality of Subotica there are missing motels near the E-75 corridor, which should be available and competitive in price. There should also be significant information points, since the significance of the information superstructure for a particular tourist destination is very important, so it is necessary to work on raising its quality constantly. Transit tourists have specific requirements, making it often difficult to organise an adequate tourist offer. The range of services in transit tourism is very diverse. It includes: fuelling service, repairing and maintenance of motor vehicles, spare parts supply, motel services, bungalows and campgrounds, food and beverage services in restaurant facilities, fast food services as well as other facilities, such as shopping malls with mega markets of the most varied range of products, sports and recreational and entertainment facilities and various service services (Garača et al., 2008, Garača et al., 2015). The organisation of tourist offer for transit tourists must be concentrated on narrow zones or corridors along the transit routes (Štetić, 1999).

Collecting data for research by transit tourists is extremely difficult, since they are constantly under time pressure, therefore they do not have enough motivation and desire to respond to surveys or participate in interviews (Kinecses and Sarah, 2016). Therefore, in the literature, the concepts "invisible tourism", "inexhaustible tourism", "unmistakable tourism", related to the tourist movements associated with the use of roads that last less than 24 hours and where there is no use of accommodation services in the categorised catering accommodation facilities (De Cantis et al., 2015). 
Based on the presented literature review, we can conclude that there is a lack of empirical study about Serbian motels, especially about their perceptions of service quality and their expectations (Pavić et al., 2018). These studies are primary focused on the hotel industry. The second, more specific research gap relates to the modest use of discriminant analysis in empirical studies in hospitality industry. The relevant studies often use multiple regression analysis and structural modelling to identify causal relations between different concepts (Clemes et al., 2011; Wu \& Chen, 2012; Arrifin \& Maghzi, 2012; Hsu et al., 2013).

The main aim of our research was to identify how different dimensions of potential guests' expectation differ between guests who travel for business and the others, who travel for leisure. In the next stage, our aim was to identify if different dimensions of guests' expectation impact on preferred service offered in Serbian motels. According to these, we decided to test two hypothesis:

$H_{1}$ : Dimensions of potential motel guests' expectations statically significant differ between guests traveling for business and guests travelling for leisure.

$\mathrm{H}_{2}$ : Different dimensions of potential motel guests' expectations have positive impact on preferred service by potential guests in Serbian motels.

\section{Research Methodology}

Questionnaire survey was the main method of data collection. Based on Ottenbacher et al. (2009) suggestion that the segment under study should be as specific as possible, the respondents of this study were potential guests of Serbian motels. The questionnaire was pretested mainly to examine the adequacy of the research instrument as well as the clarity of the questionnaire with 20 respondents. Ten of them were local tourists and the other half were foreign tourists selected randomly. The samples were selected using judgmental sampling technique based on who the researchers think would be appropriate for the study, as proposed by Ahmad, Ariffin \& Ahmad (2008). The respondents were asked, whether they would decide to stay in one of Serbian motels in the near future. If the answer obtained was positive, the person was a respondent of this study.

In this study, we used the scale of items developed by Clemes et al. (2011) and Meng \& Elliot (2008). All these items were measured on five-point scale from 1 (not important at all) to 5 (extremely important). Some items excluded from these scales or modified for the new research setting. After that, 14 dimensions of potential guests' expectations were extracted using explanatory factor analysis (EFA), presented in Table 2.

We collected the data by Internet, using Google Document form, during the period from September 1 to November 1, 2017. A total of 237 questionnaires were returned. 


\section{Results and discussion}

Table 1 presents the descriptive results of the respondents' demographic characteristics. There are more female respondents $(53.2 \%)$ than males $(46.8 \%)$. Respondents are mainly in the $31-40$ years age group accounting for $36.7 \%$ of the sample, followed by the less than 30 years age group accounting for $26.2 \%$. The single people group represents $43 \%$ of the sample. The leading occupation status category is "employed" $(80.2 \%)$, followed by "student" $(9.7 \%)$.

Table 1. Descriptive statistics

\begin{tabular}{|c|c|c|c|}
\hline Variable & Category & Frequency & Percentage \\
\hline \multirow{3}{*}{ Gender } & Male & 111 & 46.8 \\
\hline & Female & 126 & 53.2 \\
\hline & Total & 237 & 100.0 \\
\hline \multirow{5}{*}{ Age range (years) } & $<30$ & 62 & 26.2 \\
\hline & $30-39$ & 87 & 36.7 \\
\hline & $40-49$ & 48 & 20.3 \\
\hline & $50+$ & 40 & 16.9 \\
\hline & Total & 237 & 100.0 \\
\hline \multirow{4}{*}{$\begin{array}{l}\text { Monthly income } \\
\text { (RSD) }\end{array}$} & $<45696$ & 48 & 20.3 \\
\hline & 45696 to 50506 & 87 & 36.7 \\
\hline & $>50506$ & 102 & 43.0 \\
\hline & Total & 237 & 100.0 \\
\hline \multirow{6}{*}{ Occupation status } & Employed & 190 & 80.2 \\
\hline & Unemployed & 8 & 3.4 \\
\hline & Student & 23 & 9.7 \\
\hline & Pensionary & 8 & 3.4 \\
\hline & Other & 8 & 3.4 \\
\hline & Total & 237 & 100.0 \\
\hline \multirow{5}{*}{ Marital status } & Married & 40 & 16.9 \\
\hline & In a Relationship & 71 & 30.0 \\
\hline & Single & 102 & 43.0 \\
\hline & Other & 24 & 10.1 \\
\hline & Total & 237 & 100.0 \\
\hline \multirow{3}{*}{ Country of Origin } & Serbia & 63 & 26.6 \\
\hline & Abroad & 174 & 73.4 \\
\hline & Total & 237 & 100.0 \\
\hline \multirow{5}{*}{ Educational lLevel } & Secondary school & 29 & 12.2 \\
\hline & Vocational & 37 & 15.6 \\
\hline & Bachelor & 120 & 50.6 \\
\hline & Master or $\mathrm{PhD}$ & 51 & 21.5 \\
\hline & Total & 237 & 100.0 \\
\hline \multirow{3}{*}{ Growing up place } & Village & 56 & 23.6 \\
\hline & City & 181 & 76.4 \\
\hline & Total & 237 & 100.0 \\
\hline \multirow{3}{*}{ Reason for travelling } & Business & 118 & 49.8 \\
\hline & Leisure & 119 & 50.2 \\
\hline & Total & 237 & 100.0 \\
\hline
\end{tabular}




\begin{tabular}{|c|c|c|c|}
\hline Variable & Category & Frequency & Percentage \\
\hline \multirow{4}{*}{ Preferred service } & Daily rest & 16 & 6.8 \\
& Bed and breakfast & 126 & 53.2 \\
& Half board & 95 & 40.0 \\
& Total & 237 & 100.0 \\
\hline
\end{tabular}

Source: Own research

The 14 dimensions of motel guests' expectations were tested for reliability. The Cronbach's alpha for the all items ranged from 0.63 to 0.91 , all $>.60$, as recommended by Churchill (1979) for exploratory research. Cronbach's alpha indicates that these items are a very reliable measure of their pertaining constructs (Table 2). After that, items were summated using their mean scores to represent their pertaining constructs.

Table 2. Means and Cronbach's $\alpha$ for Motel Guests' Expectation Dimensions

\begin{tabular}{|c|c|c|}
\hline $\begin{array}{c}\text { Motel Guests' Expectation } \\
\text { Dimension }\end{array}$ & Mean & Cronbach's $\alpha$ \\
\hline Staff professionalism & 4.533 & 0.65 \\
\hline Accuracy of reservation & 4.833 & 0.723 \\
\hline Motel tangibles & 4.406 & 0.672 \\
\hline $\begin{array}{c}\text { Room cleanliness and } \\
\text { comfort }\end{array}$ & 4.802 & 0.631 \\
\hline Parking & 4.908 & 0.783 \\
\hline Noise level & 4.94 & 0.91 \\
\hline Security & 4.481 & 0.834 \\
\hline Accuracy of billing & 4.901 & 0.776 \\
\hline Location & 4.533 & 0.743 \\
\hline Pleasant stay & 4.829 & 0.689 \\
\hline $\begin{array}{c}\text { Physical environment of } \\
\text { motel's restaurant }\end{array}$ & 4.596 & 0.667 \\
\hline Food quality & 4.708 & 0.788 \\
\hline Communication & 4.099 & 0.801 \\
\hline Relationship bBenefits & 4.031 & 0.832 \\
\hline
\end{tabular}

Source: Own research

\subsection{Discriminant function analysis (DFA) results}

Discriminant function analysis (DFA) was used to determine motel gusts' expectation dimensions, which have impact on the differences between guest in Serbian motels who travel for business and the others who travel for leisure. The quality of the conducted DFA is presented in the Table 3.

Eigenvalue is 0.682 , which points to good quality of the discriminant function. Wilks' Lambda value, which presents quotient between variability into groups and 
overall variability, is 0.395 and it tends to 0 . Chi square value is 118.491 and it is statistically significant $(\mathrm{p}<0.01)$. It proves that there exists statistically significant difference between discriminant function means for both groups. Canonical correlation notes the strength of links between discriminant function value and dummy variable, which presents the affiliation of cases to the particular group. With its value of 0.637 , it indicates strong connectivity.

Table 3. Quality of DFA

\begin{tabular}{|c|c|c|c|c|c|c|}
\hline Eigenvalue & $\begin{array}{c}\text { \% of } \\
\text { Variance }\end{array}$ & $\begin{array}{c}\text { Canonical } \\
\text { correlation }\end{array}$ & $\begin{array}{c}\text { Wilks' } \\
\text { Lambda }\end{array}$ & $\begin{array}{c}\text { Chi- } \\
\text { square }\end{array}$ & df & Sig. \\
\hline 0.682 & 100.0 & 0.637 & 0.395 & 118.491 & 14 & 0.000 \\
\hline
\end{tabular}

Source: Own research

Table 4 shows the values of standardised coefficients that indicate the relative importance of each of the variables in the difference between groups. Variables that have a higher value of a standardized coefficient significantly contribute to the difference between groups. In the Structured Matrix column, the significance of special variables according to the significance that each of the variables has in distinguishing between groups, including the values of discriminant loadings, is shown. Based on the presented results, we can conclude that the dimensions of motel guests' expectations that most contribute to the distinction between business guests and leisure guests are "Food Quality", "Staff professionalism" and "Communication".

Table 4. Standard determination coefficients and structural matrix

\begin{tabular}{|c|c|c|}
\hline $\begin{array}{c}\text { Motel guests' expectations } \\
\text { dimension }\end{array}$ & $\begin{array}{c}\text { Standardized determination } \\
\text { coefficients }\end{array}$ & Structural matrix \\
\hline Food Quality & 0.508 & 0,330 \\
\hline Staff professionalism & 0.577 & 0,273 \\
\hline Communication & 1.001 & 0,200 \\
\hline Location & 0.597 & 0,197 \\
\hline Accuracy of billing & -0.508 & 0,197 \\
\hline Room cleanliness and comfort & 0.531 & 0,195 \\
\hline Parking & 0.452 & 0,183 \\
\hline Noise level & -0.316 & $-0,129$ \\
\hline Accuracy of reservation & -0.508 & -0.099 \\
\hline Motel tangibles & -.0433 & 0.097 \\
\hline Relationship benefits & -0.314 & -0.085 \\
\hline Security & 0.084 & 0.077 \\
\hline Pleasant stay & -0.646 & 0.016 \\
\hline $\begin{array}{c}\text { Physical environment of } \\
\text { motel's restaurant }\end{array}$ & -0.562 & 0.001 \\
\hline
\end{tabular}

Source: Own research 
Centroid represents the average disjunction value in the group. We see that for the group of business guests it is $-0,826$, while for the group of private guests it is 0,819 (Table 5).

Table 5. Functions at Group Centroids

\begin{tabular}{|c|c|}
\hline Reason for Traveling & Function \\
\hline Business & -0.826 \\
\hline Private/Leisure & 0.819 \\
\hline
\end{tabular}

Source: Own research

The classical matrix shows the number of respondents who are properly sorted in each of the groups. The performance of the classification is expressed with the value of the Hit ratio, the relation between the correctly sorted cases and the total number of cases or respondents in the sample. In our case, the value is $84.4 \%$ (Table 6).

Table 6. Classification Results

\begin{tabular}{|c|c|c|c|c|}
\hline \multirow{2}{*}{$\begin{array}{c}\text { Rumber of } \\
\text { travelling }\end{array}$} & Business & Business & Leisure/Private & \multirow{2}{*}{ Total } \\
\cline { 3 - 4 } cases & Leisure/Private & 15 & 22 & 118 \\
\hline \multirow{2}{*}{$\%$} & Business & 81.4 & 104 & 119 \\
\cline { 2 - 4 } & Leisure/Private & 12.6 & 18.6 & 100.0 \\
\hline \multicolumn{2}{|l}{$84.4 \%$ of original grouped cases correctly classified. } \\
\hline
\end{tabular}

Source: Own research

\subsection{Canonical Varieties Analysis (CVA) results}

Using the Canonical Varieties Analysis (CVA) or multiple discriminant analysis method, we wanted to determine how we could split the respondents into preferred motel services in relation to the expectations of potential motel guests. With a view to the fact that the respondents selected a daily break, bed and breakfast and half board as potentially preferred services, we conducted a multiple discriminant analysis.

Given the fact that the respondents should be classified into three groups, we have obtained two discriminant functions, presented in Table 7. Based on the results presented, we conclude that the first function has a greater eigenvalue, and thus allows better distinction between groups. Based on Wilks' $\lambda$ value, $\chi^{2}$ and degree of significance, we conclude that the first function allows for better differentiation between groups: the small value of Wilks' $\lambda$, the degree of significance $p<0.01$. For the second function, we can say that only a slight difference in the group's differences exists, given that the Wilks' $\lambda$ value is greater than the recommended limit of 0.5 . However, the $\chi^{2}$ are also statistically significant $(\mathrm{p}<0.01)$. 
Table 7. Quality of DFA

\begin{tabular}{|c|c|c|c|c|c|c|c|}
\hline Function & Eigenvalue & $\begin{array}{c}\% \text { of } \\
\text { Variance }\end{array}$ & $\begin{array}{c}\text { Canonical } \\
\text { correlation }\end{array}$ & $\begin{array}{c}\text { Wilks' } \\
\lambda\end{array}$ & $\mathrm{X}^{2}$ & $\mathrm{df}$ & Sig. \\
\hline 1 & 2.715 & 87.2 & 0.855 & 0.192 & 375.063 & 28 & 0.000 \\
\hline 2 & 0.400 & 12.8 & 0.534 & 0.714 & 76.501 & 13 & 0.000 \\
\hline
\end{tabular}

Source: Own research

Based on the data presented in the structural matrix (Table 8) we can conclude that the first function is related to the dimensions of the expectations "Professional staff," "Communication", "Noise" and "Accuracy of reservation", while the other function is related to other dimensions of guest expectations.

Table 8. Structural matrix for both discriminant functions

\begin{tabular}{|c|c|c|}
\hline \multirow{2}{*}{$\begin{array}{c}\text { Motel guests' expectations } \\
\text { dimension }\end{array}$} & 1 & 2 \\
\cline { 2 - 3 } & $0.423^{*}$ & -0.322 \\
\hline Staff professionalism & $0.150^{*}$ & 0.009 \\
\hline Communication & $0.137^{*}$ & -0.058 \\
\hline Noise level & $0.018^{*}$ & 0.014 \\
\hline Accuracy of reservation & -0.270 & $-0.382^{*}$ \\
\hline Location & -0.149 & $-0.366^{*}$ \\
\hline Motel tangibles & -0.118 & $0.340^{*}$ \\
\hline Security & -0.062 & $-0.241^{*}$ \\
\hline Food quality & 0.007 & $-0.229^{*}$ \\
\hline Parking & -0.067 & $0.158^{*}$ \\
\hline Accuracy of billing & -0.042 & $-0.140^{*}$ \\
\hline Room cleanliness and comfort & -0.051 & $-0.128^{*}$ \\
\hline Pleasant stay & -0.033 & $0.069^{*}$ \\
\hline $\begin{array}{c}\text { Physical environment of } \\
\text { motel's room }\end{array}$ & 0.005 & $-0.054^{*}$ \\
\hline Relationship benefits & & \\
\hline * connection of a variable with a certain discriminant function & \\
\hline
\end{tabular}

Source: Own research

From the results presented in Table 9, it can be concluded that the group that would prefer Bed and Breakfast has the greatest expectation from Staff professionalism, Communication, Noise level and Accuracy of reservation. Group that prefer Half board has the middle importance of the above mentioned dimensions, while the group that prefer Daily rest has the least expectation from Staff professionalism, Communication, Noise level and Accuracy of reservation. 
Pavić et al. / Economic Themes, 56(4): 503-517

Table 9. Group statistics

\begin{tabular}{|c|c|c|c|c|}
\hline \multicolumn{2}{|c|}{$\begin{array}{l}\text { Which service would you be prepared to } \\
\text { use in one of Serbian motels? }\end{array}$} & \multirow{2}{*}{$\begin{array}{l}\text { Mean } \\
4.2500\end{array}$} & \multirow{2}{*}{$\begin{array}{c}\text { Standard Deviation } \\
0.4556\end{array}$} & \multirow{2}{*}{$\begin{array}{l}\mathrm{N} \\
16\end{array}$} \\
\hline \multirow{14}{*}{ Daily rest } & $\begin{array}{c}\text { Staff } \\
\text { professionalism }\end{array}$ & & & \\
\hline & $\begin{array}{l}\text { Accuracy of } \\
\text { rReservation }\end{array}$ & 4.8594 & 0.15729 & 16 \\
\hline & Motel tTangibles & 4.500 & 0.7377 & 16 \\
\hline & $\begin{array}{c}\text { Room cleanliness } \\
\text { and comfort }\end{array}$ & 4.8239 & 0.12183 & 16 \\
\hline & Parking & 4.8750 & 0.12910 & 16 \\
\hline & Noise level & 4.8333 & 0.17213 & 16 \\
\hline & Security & 4.7500 & 0.25820 & 16 \\
\hline & Accuracy of billing & 5.000 & 0.000 & 16 \\
\hline & Location & 4.8333 & 0.17213 & 16 \\
\hline & Pleasant stay & 4.8750 & 0.12910 & 16 \\
\hline & $\begin{array}{c}\text { Physical } \\
\text { environment of } \\
\text { motel's restaurant }\end{array}$ & 4.6667 & 0.000 & 16 \\
\hline & Food quality & 4.7500 & 0.25820 & 16 \\
\hline & Communication & 3.7500 & 0.000 & 16 \\
\hline & $\begin{array}{c}\text { Relationship } \\
\text { Benefits }\end{array}$ & 4.000 & 0.344427 & 16 \\
\hline \multirow{14}{*}{ Bed and Breakfast } & $\begin{array}{c}\text { Staff } \\
\text { professionalism }\end{array}$ & 4.5756 & 0.11966 & 126 \\
\hline & $\begin{array}{l}\text { Accuracy of } \\
\text { reservation }\end{array}$ & 4.8313 & 0.24255 & 126 \\
\hline & Motel tangibles & 4.3594 & 0.16634 & 126 \\
\hline & $\begin{array}{l}\text { Room cleanliness } \\
\text { and comfort }\end{array}$ & 4.7864 & 0.13524 & 126 \\
\hline & Parking & 4.8909 & 0.17747 & 126 \\
\hline & Noise level & 4.9524 & 0.12447 & 126 \\
\hline & Security & 4.5000 & 0.25298 & 126 \\
\hline & Accuracy of billing & 4.9048 & 0.19712 & 126 \\
\hline & Location & 4.4365 & 0.26487 & 126 \\
\hline & Pleasant sStay & 4.8056 & 0.23214 & 126 \\
\hline & $\begin{array}{c}\text { Physical } \\
\text { environment of } \\
\text { motel's Restaurant }\end{array}$ & 4.5979 & 0.26772 & 126 \\
\hline & Food quality & 4.6726 & 0.25974 & 126 \\
\hline & Communication & 4.1528 & 0.37679 & 126 \\
\hline & $\begin{array}{c}\text { Relationship } \\
\text { benefits }\end{array}$ & 4.0212 & 0.49843 & 126 \\
\hline
\end{tabular}




\begin{tabular}{|c|c|c|c|c|}
\hline \multicolumn{2}{|c|}{$\begin{array}{l}\text { Which service would you be prepared to } \\
\text { use in one of Serbian motels? }\end{array}$} & Mean & Standard Deviation & $\mathrm{N}$ \\
\hline \multirow{14}{*}{ Half board } & $\begin{array}{c}\text { Staff } \\
\text { professionalism }\end{array}$ & 4.5740 & 0.11079 & 95 \\
\hline & $\begin{array}{l}\text { Accuracy of } \\
\text { reservation }\end{array}$ & 4.8316 & 0.21401 & 95 \\
\hline & Motel tangibles & 4.4526 & 0.14233 & 95 \\
\hline & $\begin{array}{l}\text { Room cleanliness } \\
\text { and comfort }\end{array}$ & 4.8191 & 0.17110 & 95 \\
\hline & Parking & 4.9368 & 0.15021 & 95 \\
\hline & Noise level & 4.9439 & 0.12541 & 95 \\
\hline & Security & 4.4105 & 0.34192 & 95 \\
\hline & $\begin{array}{l}\text { Accuracy of } \\
\text { bBilling }\end{array}$ & 4.8789 & 0.21532 & 95 \\
\hline & Location & 4.6105 & 0.18612 & 95 \\
\hline & Pleasant stay & 4.8526 & 0.21726 & 95 \\
\hline & $\begin{array}{c}\text { Physical } \\
\text { environment of } \\
\text { motel's restaurant }\end{array}$ & 4.5825 & 0.34024 & 95 \\
\hline & Food quality & 4.7500 & 0.10314 & 95 \\
\hline & Communication & 4.0868 & 0.46381 & 95 \\
\hline & $\begin{array}{l}\text { Relationship } \\
\text { benefits }\end{array}$ & 4.0491 & 0.37965 & 95 \\
\hline
\end{tabular}

Source: Own research

\section{Conclusion}

According to the presented results, we can conclude that discriminant analysis is effective tool for predicting potential demand in Serbian motels. Both Hypotheseis, $\mathrm{H}_{1}$ and $\mathrm{H}_{2}$ were partially accepted.

Based on presented results for Hypothesis 1, it has been determined that dimensions of motel guests' expectations that most contribute to the distinction between business guests and leisure guests are "Food quality", "Staff professionalism" and "Communication". Leisure guests have greater expectation about these dimensions comparing with business guests. These facts also improves the value of hit ratio, $84.4 \%$ correctly sorted cases in these two groups.

Based on presented results for Hypothesis 2, it has been determined that conclude that the dimensions of the expectations "Professional staff," "Communication", "Noise" and "Accuracy of reservation" moderate the demand and the preferred service in Serbian motels. The group that would prefer"Bed and Breakfast" has the greatest expectation from "Staff professionalism", "Communication", "Noise level" and "Accuracy of reserve ation". Group that prefers Half board has the middle 
importance of the above mentioned dimensions, while the group that prefer "Daily rest" has the least expectation from "Staff professionalism", "Communication", "Noise level" and "Accuracy of reservation".

Future research in the field of motel management should include other multivariate analysis, such as cluster analysis, to specify the potential target groups of the Serbian motels' guests. Future research in this area should also include socio-demographic variables as a predictive tool to determine its moderate role in potential guests' expectation. Last but not the least, it is necessary to investigate current situation in Serbian motels regarding offered services and guests' satisfaction. There results should be compared with our results and would be a useful tool for motel managers to increase demand for motel services.

\section{References}

Ahmad, M., Ariffin, A., \& Ahmad, A. (2008). Evaluating the services of Malaysian hotels from leisure traveller's perspectives. Jurnal Pengursuran, 27, 69-83.

Afiffin, A., \& Maghzi, A. (2012). A preliminary study on customer expectations on hotel hospitality: Influences of personal and hotel factors. International Journal of Hospitality Management, 31, 191-198.

Bastič, M. (2006). Metode raziskovanja. Maribor: Ekonomsko-poslovna fakulteta.

Bergin-Seers, S., \& Jago, L. (2007). Performance measurement in small motels in Australia. Tourism and Hospitality Research, 7(2), 144-155.

Churchill, G. (1979). A paradigm for developing better measures of marketing constructs. Journal of Marketing Research, 16, 64-73.

Clemes, D., Gan, C., \& Ren, M. (2011). Synthesizing the Effects of Service Quality, Value, and Customer Satisfaction on Behavioural Intention in Motel Industry: An Empirical Analysis. Journal of Hospitality \& Tourism Research, 35(4), 530-568.

De Cantis, S., Parroco, A., Ferrante, M., \& Vaccina, F. (2015). Unobserved tourism. Annals of Tourism Research, 50, 1-18.

Garača, V., Jovanović, G., \& Zakić, L. (2008). Analiza prometa na delu autoputa E-75 kroz Bačku u funkciji tranzitnog turizma. Zbornik radova Geografskog fakulteta, LVI, 131142.

Garača, V., Jovanović, G., Ćurčić, N., \& Vukosav, S. (2015). Spatial planning for transit tourism on the highway: A case study of highway E-75 through Vojvodina (Horgoš Belgrade section). Transilvanian Review of Administrative Sciences, 44 E, 126-143.

Horak, S. (2004). Teorijska razmatranja i tranzitni turizam. Ceste i mostovi: glasilo Hrvatskog društva za ceste, 3(4), 107-112.

Hsu, S., Tsai, M., \& Wang, Y. (2013). Developing a decomposed customer satisfaction index: An example of the boutique motel industry. Total Quality Management, 24(10), 11241140 .

Kinecses, A., Toth, G., Tomori, N., \& Michalko, G. (2016). Characteristics of transit tourism in Hungary with a focus of expenditure. Regional Statistics, 6(2), 129-148.

Knežević, R., \& Grbac Živković, R. (2013). Promjene gospodarskog značenja tranzitnog turizma u Gorskom kotaru. Hrvatski geografski glasnik, 75(1), 111-130. 
Kovačević, T., \& Obradović, S. (2006). Postoji li tranzitni turizam u Srbiji? - primer opštine Subotica. Turizam, 10, 40-41.

Kovačić, J. Z. (1994). Multivarijaciona analiza. Beograd: Ekonomski fakultet.

Mair, J., \& Bergin-Seers, S. (2010). The effect of interventions on the environmental behaviour of Australian motel guests. Tourism and Hospitality Research, 10(4), 255-268.

Mazzeo, M. (2004). Retail contracting and organizational form: Alternatives to chain affiliation in the motel industry. Journal of Economics \& Management Strategy, 13(4), 599-615.

Meng, J., \& Eliott, K. (2008). Predictors of relationship quality for luxury restaurants. Journal of Retailing and Consumer Services, 15, 509-515.

Ministry of Trade, Tourism and Telecommunication of the Republic of Serbia, http://mtt.gov.rs/en/, Accessed on 29 July 2018.

Ottenbacher, M., Harrington, R., \& Parsa, H. (2009). Defining the hospitality discipline: a discussion of pedagogical and research implications. Journal of Hospitality and Tourism Research, 33(3), 263-283.

Pavić, L., Blešić, I., Nerandžić, B., Vukosav, S., Mumel, D. (2018). Motels in Serbia - What Do Potential Guests Expect? Industrija, 46(2), 65-76.

Štetić, S. (1984). Tranzitni turizam u regionalnom razvoju. Turizam: međunarodni znanstvenostručni časopis, 1, 34-46.

Štetić, S. (1999). Turistička geografija. Beograd: Savezni centar za unapređenje hotelijerstva ugostiteljstva.

Tabachnick, B., Fidell, L. (2007). Using Multivariate Statistics. Boston: Pearson Education.

Wu, S., \& Chen, J. (2012). Comparison between hotels and motels using CRM effect model An empirical study in Taiwan. International Journal of Hospitality Management, 31, 1254-1263.

Wu, S., \& Lu, C. (2012). The relationship between CRM, RM, and business performance: a study of the hotel industry in Taiwan. International Journal of Hospitality Management, 31(1), 276-285.

\section{DISKRIMINACIONA ANALIZA - KORISNO ORUĐE ZA PREDVIĐANJE TRAŽNJE U MOTELIMA U SRBIJI}

Apstrakt: U radu je predstavljen značaj disrkiminacione analize kao korisnog oruđa za predviđanje tražnje u motelima u Srbiji. Kroz predstavljeni pregled literature utvrđeno je da ne postoji veliki broj istraživanja koja su sa bavila pitanjem potreba tranzitnih turista, uprkos činjenici da tranzitni turizam jeste jedan od prioritetnih oblika turizma za Republiku Srbiju, u skladu sa postavljenom Strategijom razvoja turizma u Republici Srbiji za tekući period. Anketni upitnik korišćen je kao glavni metod za prikupljanje podataka. Na osnovu rezultata izdvojeno je 14 dimenzija očekivanja potencijalnih gostiju motela u Srbiji. Rezultati diskriminacione funkcijske analize pokazali su kako očekivanja potencijalnih gostiju motela u Srbiji utiču na glavni razlog putovanja gostiju, dok su rezultati kanoničke varijacione analize pokazali uticaj tih očekivanja na preferiranu uslugu u motelima u Srbiji.

Ključne reči: Diskriminaciona analiza, motel, dimenzije očekivanja gostiju, Srbija, ugostiteljstvo, tranzitni turizam 


\section{Authors' biographies}

Lazar Pavić, MSc is a research associate at Economics Institute in Belgrade and $\mathrm{PhD}$ student of Tourism and Hospitality Management at The University of Novi Sad, Faculty of Sciences. His research interests are hospitality management, human resources management and marketing and consumer behaviour. He is especially interested in using qualitative methods in hospitality management studies.

Božidar Veljković, $\mathrm{PhD}$ is an assistant professor at Alma Mater Europaea European center in Maribor, Slovenia. His research interests are political science, tourism management, communication management and communication in tourism.

Bojan Sešel, MSc is a director and a lecturer at Higher professional school in Celje, Slovenia. He is especially interested in microeconomics, entrepreneurship, performance management and human resources management. 